
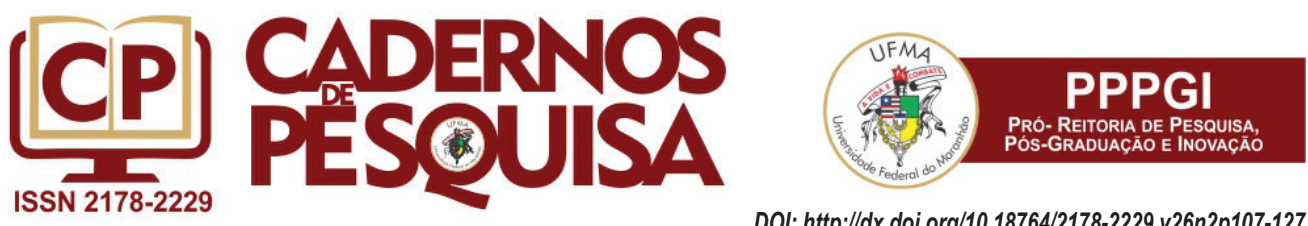

DOI: http://dx.doi.org/10.18764/2178-2229.v26n2p107-127

\title{
A PRESENCCA DOS FUNDAMENTOS DA PEDAGOGIA SOCIAL NO ENSINO DE LÍNGUA PORTUGUESA PARA MIGRANTES E REFUGIADOS EM SÃO PAULO
}

\author{
THE PRESENCE OF THE FOUNDATIONS OF SOCIAL \\ PEDAGOGY IN THE TEACHING OF PORTUGUESE LANGUAGE \\ FOR MIGRANTS AND REFUGEES IN SÃO PAULO
LA PRESENCIA DE LOS FUNDAMENTOS DE LA PEDAGOGÍA SOCIAL EN LA ENSEÑANZA DE LENGUA PORTUGUESA PARA MIGRANTES Y REFUGIADOS EN SAO PAULO

\author{
Rita de Cássia da Cruz Silva \\ Doutoranda na Faculdade de Educação da Universidade de São Paulo \\ poetike@gmail.com \\ Régis Minvielle \\ Universidade Aix-Marseille. Marseille-Provance, França. \\ minviellergis@yahoo.fr
}

\begin{abstract}
Resumo
O Brasil passou a figurar como rota dos novos fluxos migratórios globalizados ao receber migrantes e refugiados. Sendo o país signatário dos principais tratados e pactos internacionais de Direitos Humanos, é preciso se questionar acerca da garantia dos direitos dessa população, sobretudo dos direitos educativos. Para que essas pessoas tenham mais chances de permanecer na escola, assimilar os conteúdos e participar de uma aprendizagem com relevância, são necessárias ações que promovam o ensino da língua portuguesa. Assim, este artigo tem como objetivo investigar a presença (e a importância) de fundamentos da Pedagogia Social no início da trajetória escolar de migrantes e refugiados, quando da sua participação em cursos de língua portuguesa ofertados pelo Estado e/ou pelas Organizações da Sociedade Civil. Como metodologia de trabalho, utilizamos os procedimentos dos estudos descritivos e realizamos uma breve análise do conceito de Pedagogia Social, a caracterização dos cursos de língua portuguesa oferecidos pela Missão Paz e pelo projeto Portas Abertas. Ao final, apresentamos o depoimento de uma educadora que trabalhou na Missão Paz e na E.M.E.F. Infante Dom Henrique, a escola que inspirou a criação do projeto Portas Abertas. A partir da análise conceitual, concluímos que, embora os referidos projetos desenvolvam algumas práticas formais de educação/escolarização, ambos apresentam princípios da Pedagogia Social, reforçando a consciência de que o direito à educação não é apenas o de ir à escola, mas o de aprender na escola.
\end{abstract}

Palavras-chave: Migrantes, Refugiados, Educação, Pedagogia Social.

\begin{abstract}
Brazil began to appear as a route of the new globalized migratory flows when receiving migrants and refugees. As the signatory country of the main international human rights treaties and agreements, it is necessary to question the guarantee of the rights of this population, especially of educational rights. In order for these people to be more likely to remain in school, assimilate content and participate in relevant learning, actions are necessary to promote the teaching of the Portuguese language. Thus, this article aims to investigate the presence (and importance) of foundations of Social Pedagogy at the beginning of the school trajectory of migrants and refugees, when participating in Portuguese language courses offered by the State and / or Civil Society Orga As a working methodology, we used the procedures of the descriptive studies and carried out a brief analysis of the concept of Social Pedagogy the characterization of the Portuguese Language courses offered by the Peace Mission and the Open Doors project. At the end, we present the testimony of an educator who worked at the Peace Mission and in E.M.E.F. Infante Dom Henrique, the school that inspired the creation of the Open Doors project. From the conceptual analysis, we conclude that, although these projects develop some formal education / schooling practices, both present principles of Social
\end{abstract}

Artigo recebido em dezembro 2018. Aprovado em junho de 2019.

Cad. Pesq., v. 26, n. 2, abr./jun., 2019. 
Pedagogy, reinforcing the awareness that the right to education is not just to go to school, but to learn at school.

Keywords: Migrants, Refugees, Education, Social Pedagogy.

\section{Resumen}

Brasil pasó a figurar como ruta de los nuevos flujos migratorios globalizados, al recibir migrantes y refugiados. Siendo el país signatario de los principales tratados y pactos internacionales de Derechos Humanos, es necesario preguntarse acerca de la garantía de los derechos de esa población, sobre todo de los derechos educativos Para que estas personas tengan más posibilidades de permanecer en la escuela, para asimilar los contenidos y participar en un aprendizaje pertinente, son necesarias acciones para promover la enseñanza de la lengua portuguesa. Así, este artículo tiene como objetivo investigar la presencia (y la importancia) de los fundamentos de la Pedagogía Social en el comienzo de la vida escolar de los migrantes y refugiados, al participar en los cursos de lengua portuguesa ofrecidos por el Estado y / o por las Organizaciones de la Sociedad Civil . Como metodología de trabajo, se utilizamos los procedimientos de estudios descriptivos y realizamos un breve análisis del concepto de pedagogía social, la caracterización de los cursos de lengua portuguesa ofrecidos por los proyectos "Missão Paz" y "Portas Abertas". Al final, presentamos el testimonio de una educadora que trabajó en la "Missão Paz" y en la E.M.E.F. Infante Dom Henrique, la escuela que inspiró la creación del proyecto "Portas Abertas". A partir del análisis conceptual, llegamos a la conclusión de que aunque los proyectos de la "Missão Paz" y de "Portas Abertas" presenten algunas prácticas formales de educación / escolarización, ambos presentan principios de la Pedagogía Social, reforzando la conciencia de que el derecho a la educación no es sólo el derecho a ir a la escuela, pero el derecho a aprender en la escuela.

Palabras-llave: Migrantes, Refugiados, Educación, Pedagogía Social.

\section{Introdução}

OBrasil - cuja história é marcada pelos mais diversos processos de migração, desde os primórdios de sua constituição como país - passou a figurar, nas últimas décadas, como rota dos novos fluxos migratórios globalizados. Isso se deve, principalmente, ao aumento do percentual de deslocados no mundo e também à difundida política de fechamento de fronteiras praticada pelos países da União Europeia. Segundo o relatório International Migration Flows to and From Selected Countries: The 2015 Revision - da OIM, agência das Nações Unidas especializada no tema -, o número de migrantes internacionais aumentou mais rápido que o crescimento em escala global da população nos últimos anos, passando de 2,8\% do contingente, em 2000, para 3,3\% em 2015.

É importante destacar que, a partir do início da década de 1990 e, com mais expressão, nos anos 2000, os fluxos migratórios se diversificaram: multipolares, eles passaram a ser exercidos não apenas em direção a países do Hemisfério Norte e a áreas com maior concentração de renda e empregos, mas, também, a países emergentes do Hemisfério Sul - a chamada migração Sul-Sul. Inclusive, como ressalta a professora Lesley Bartlett, da Universidade de Wisconsin-Madison, os "migrantes Sul-Sul" têm maior probabilidade que os "migrantes Sul-Norte" de estar sem documentos, e, portanto, de se tornarem trabalhadores precários, frequentemente excluídos dos serviços sociais de saúde e educação (BARTLETT et al, 2015, p. 1.156).

No caso do Brasil, o país passou então a receber não apenas aqueles provenientes dos países fronteiriços - os denominados migrantes regionais -, mas também migrantes de outras partes do mundo, provenientes das novas rotas migratórias globalizadas.

Antes de prosseguir, é premente fazer uma importante distinção entre os que se deslocam: aqueles que são obrigados a deixar seus territórios mediante grave ameaça ou risco de morte - por motivos de guerra, raça, religião, nacionalidade, grupo social ou opinião política, conflitos armados, violência generalizada e violação dos direitos humanos - são chamados também de refugiados; os outros, que migram por diversos fatores, entre estes a busca de melhores condições de vida, são denominados apenas de migrantes, ainda que possam ser divididos em muitas e diversificadas categorias. 
De acordo com os dados da Polícia Federal, em relação ao número total de migrantes internacionais, até 2016, havia aproximadamente 1,7 milhão de estrangeiros vivendo no Brasil, dos quais 385.120 estavam registrados na cidade de São Paulo (IPPDH, 2017, p. 21 e 22).

Já nos dados específicos de refugiados reunidos pelo Conare (Comitê Nacional para os Refugiados), os principais pedidos de refúgio no Brasil, em 2017, partiram dos seguintes países: Venezuela: 17.865 pessoas; Cuba: 2.373; Haiti: 2.362; Angola: 2.036; China: 1.462; Senegal: 1.221; Síria: 823; Nigéria: 549; Bangladesh: 523; e República Democrática do Congo: 364. Logo, pode-se perceber que apenas em um curto período no caso, o ano de 2017 - foram expedidos 33.866 pedidos de refúgio no país (CONARE, 2017). Os números de refúgio específicos para a cidade de São Paulo, no mesmo ano, revelam que houve quase 10 mil pedidos, o que representa $28 \%$ do total de solicitações de todo o país no período.

Ora, a partir desses números, podemos perceber que o Brasil, definitivamente, surge como "etapa" ou "assentamento" nas novas rotas de migração globalizada. Se até o início dos anos 2000, estávamos "acostumados" apenas com a presença boliviana e, posteriormente, com os haitianos, hoje já existe um ponto de mudança na história da migração transatlântica Sul-Sul, justamente no sentido de consolidação desse fluxo migratório específico em nosso território.

Nesse sentido, os (novos) territórios de acolhimento começam a lidar com os desafios que a recepção dessas populações enseja, começando pelo fato de que tanto refugiados quanto aqueles denominados apenas migrantes possuem direitos consagrados mundialmente.

Diante de um cenário no qual o Brasil passa a figurar como receptor de deslocados - tanto migrantes quanto refugiados - e sendo o país signatário dos principais tratados e pactos internacionais de Direitos Humanos, não há dúvidas de que é urgente se questionar acerca da garantia dos direitos dessa população.

Além dos Tratados e Protocolos Internacionais dos quais o Brasil é signatário, devemos lembrar que a própria legislação do país garante direitos aos migrantes e refugiados, sobretudo os direitos educativos. Atualmente, as leis nacionais determinam que estrangeiros tenham direito ao acesso à educação da mesma forma que os brasileiros, conforme expresso pela Constituição Federal (artigos $5^{\circ}$ e $6^{\circ}$ ), pelo Estatuto da Criança e do Adolescente (artigos $53^{\circ}$ ao $55^{\circ}$ ) e pela Lei de Diretrizes e Bases da Educação Nacional (artigos $2^{\circ}$ e $3^{\circ}$ ).

Afora os ordenamentos jurídicos supracitados, há leis específicas para essas populações: a Lei dos Refugiados, $n^{\circ} 9.474 / 97^{1}$ (artigos $43^{\circ}$ e $44^{\circ}$ ) - que garante a eles documentos básicos, incluindo aqueles de identificação e de trabalho, além da liberdade de movimento no território nacional e de outros direitos civis: em território brasileiro, o refugiado pode trabalhar, estudar e exercer os mesmos direitos que qualquer cidadão estrangeiro em situação regular no país - e a Lei no 13.445/2017², também chamada de "Nova Lei de Migração", que revoga o Estatuto do Estrangeiro e traz novo ordenamento pautado na visão do migrante como sujeito de direitos.

Na cidade de São Paulo, especificamente, existe a Lei Municipal $n^{\circ} 16.478^{3}$, de 8 de julho de 2016, que instituiu de forma pioneira no país a PMPI - Política Municipal para a População Imigrante. De acordo com o seu Decreto Regulamentador ( $n^{\circ} 57.533^{4}$, de 15 de dezembro de 2016), os migrantes e refugiados da cidade de São Paulo devem receber serviços de saúde, assistência social e educação, independentemente de sua situação migratória e documental.

\footnotetext{
Lei Federal n 9.474/97. Disponível em: <www.planalto.gov.br/ccivil_03/leis/L9474.htm>. Acesso em: 25 nov. 2018.

2 Lei Federal n 13.445/2017. Disponível em: <www.planalto.gov.br/ccivil_03/_ato2015-2018/2017/lei/L13445.htm>. Acesso em: 25 nov. 2018.

3 Lei Municipal $n^{0}$ 16.478/2017. Disponível em: <www3.prefeitura.sp.gov.br/cadlem/secretarias/negocios_juridicos/cadlem/integra. asp?alt=09072016L\%20164780000>. Acesso em: 25 nov. 2018.

4 Decreto Municipal n 57.533/2016. Disponível em: <http://legislacao.prefeitura.sp.gov.br/leis/decreto-57533-de-15-de-dezembro-de-2016/>. Acesso em: 25 nov. 2018.
} 
No âmbito estadual, apesar de não haver ainda uma legislação aprovada, existem algumas normativas que garantem o acesso à escolarização formal para migrantes e refugiados, nos mesmos termos estabelecidos pela legislação municipal. Atualmente, vigora o parecer do Conselho Estadual de Educação ( $\left.n^{\circ} 633 / 2008\right)$ que garante o direito de matrícula de crianças, jovens e adultos estrangeiros, mesmo que não tenham a documentação adequada.

Com a "presumida" facilitação do acesso à escolarização formal dos migrantes e refugiados, o número de inscritos nas redes dobrou nos últimos anos. De acordo com dados do Censo Escolar, realizado pelo Instituto Nacional de Estudos e Pesquisas Educacionais Anísio Teixeira - Inep, do Ministério da Educação, entre 2008 e 2016, o número de matrículas de alunos de outras nacionalidades em escolas brasileiras saltou de 34 mil para quase 73 mil registros (INSTITUTO UNIBANCO, 2018).

Em relação às matrículas de EJA (Educação de Jovens e Adultos) - cujo público é foco desta pesquisa -, os números ainda são tímidos: em 2016, havia em todo o país menos de cinco mil estrangeiros nos bancos escolares. Isso, contudo, não significa que tal modalidade deva ser negligenciada no contexto das migrações. Ao contrário: os deslocados jovens e adultos que chegam ao Brasil, via de regra, já estão inseridos (ou em idade de inserção) no mercado de trabalho (formal ou informal) e contribuem ativamente para o remodelamento social e econômico dos territórios onde fixam moradia.

Considerando, então, os jovens e adultos, sabemos que apenas o acesso à matrícula pode não configurar a efetivação de seus direitos educativos. Isso porque, de fato, estar oficialmente inscrito em uma escola não garante o sucesso em sua nova trajetória escolar. Frequentemente, essa população tem esbarrado em violações ligadas às questões da aceitabilidade (não é aceitável uma educação que discrimina) e à adaptabilidade (uma educação cujas diferenças são ignoradas e apagadas, a começar pelas especificidades linguísticas).

Uma das maiores dificuldades encontradas no processo de escolarização formal - e relatadas expressamente por migrantes e refugiados - é o aprendizado da língua portuguesa. Não é exagero afirmar que a falta de conhecimento do código linguístico acaba causando enormes dificuldades de inserção e permanência na escola. Consequentemente, essa barreira torna-se um obstáculo também na inserção social plena do migrante no território de acolhimento, inclusive, com reflexos no acesso e efetivação de seus outros direitos, tais como moradia, justiça, trabalho e saúde.

Em geral, para que alunos estrangeiros - desde as crianças até os jovens e adultos - tenham mais chances de permanecer na escola, acompanhar as aulas, assimilar os conteúdos propostos e participar de uma aprendizagem com relevância, são necessárias adaptações nas práticas pedagógicas e ações que promovam o ensino da língua portuguesa (antes ou concomitantemente às aulas na educação escolar formal), permitindo a integração e a adequação às diferenças culturais de sua nova realidade social.

É sobre este momento - estabelecido como "antes" ou "concomitante" ao início da trajetória escolar formal do migrante em São Paulo, quando ele está aprendendo a língua portuguesa - que nos debruçamos para investigar se há a presença (bem como se há importância) dos fundamentos da Pedagogia Social, escudando essa população em seu processo de aprendizagem. Considerando que a Pedagogia Social é o campo de conhecimento no qual estão inseridas a educação popular, a educação social e a educação comunitária, e que, atualmente, o Estado (em todos os seus níveis federativos) não é capaz de oferecer, sozinho, uma ampla rede de ensino de língua portuguesa para essa população, o papel do educador social - sobretudo daqueles que desenvolvem seus trabalhos, como voluntários, nas Organizações da Sociedade Civil - torna-se não apenas relevante, mas imprescindível, para amenizar os obstáculos que surgirão na trajetória escolar formal de migrantes e refugiados. 
Assim, este artigo tem como objetivo investigar se há fundamentos da Pedagogia Social nas iniciativas de oferta de cursos de língua portuguesa no início da trajetória escolar de migrantes e refugiados, bem como a importância/relevância desses fundamentos no seu processo de socialização, integração e garantia de direitos nas sociedades de acolhimento. Nosso objetivo, por ora, não é fazer uma análise exaustiva dessas iniciativas, mas uma análise capaz de reconhecer em suas bases a presença (ou a ausência) dos fundamentos da Pedagogia Social em alguns serviços ofertados pelo Estado e/ou pelas Organizações da Sociedade Civil.

Para melhor compreender como tais iniciativas podem ser importantes no processo de socialização de migrantes e refugiados, neste artigo, realiza-se uma descrição/caracterização de duas experiências distintas: o curso oferecido pela Missão Paz - uma Organização da Sociedade Civil, de caráter confessional, fundada pela congregação católica dos missionários escalabrinianos - e o Projeto Portas Abertas, executado no âmbito da Prefeitura do Município de São Paulo, que visa o oferecimento de cursos de língua portuguesa nas escolas da rede. Como metodologia de trabalho, fazemos uma breve análise do conceito de Pedagogia Social, bem como da sua base freireana de sustentação aplicada à realidade da migração e do refúgio. Ainda utilizando os procedimentos dos estudos descritivos, especificamos os perfis, propriedades e características dos serviços de acolhimento e dos cursos de Língua Portuguesa oferecidos pela Missão Paz e do projeto Portas Abertas e, ao final, apresentamos o depoimento de uma educadora que desempenhou trabalhos na Missão Paz e na E.M.E.F. Infante Dom Henrique, a escola que inspirou a criação do referido projeto.

Espera-se que os resultados deste artigo contribuam para a melhoria da oferta de cursos de Língua Portuguesa como forma de socialização e acolhimento; como parte imprescindível no processo de inserção e permanência na escolarização formal, mas, sobretudo, na construção da autonomia, da independência e da cidadania plena de migrantes e refugiados na cidade de São Paulo.

\section{Os fundamentos da Pedagogia Social para a educação de migrantes e refugiados}

De forma geral, podemos dizer que a Pedagogia Social é a teoria que fundamenta a prática da Educação Social, que - por sua vez -, no Brasil, abrange as práticas educativas rotuladas como não formais.

As práticas da Pedagogia Social estão inseridas na Educação Popular, Educação Sociocomunitária e em outras práticas educativas que não são estritamente escolares. Como um campo da ciência, ela se preocupa, sobretudo, com as questões relativas às sociedades e à formação para o desenvolvimento humano necessária à sobrevivência nesses espaços. Podemos dizer ainda que a Pedagogia Social é uma ciência complementar na busca da educação integral, aquela que não pretende separar o "mundo da vida" do "mundo da escola" (SILVA et al, 2011, p. 6).

Além disso, tal ciência visa à inclusão social e à formação cultural de grupos historicamente marginalizados, como a população quilombola, a população do campo, os povos indígenas, os encarcerados, os adolescentes em medidas socioeducativas, os deficientes físicos e mentais, as mulheres em situação de violência doméstica, as comunidades carentes em territórios de extrema vulnerabilidade social etc. No contexto deste artigo, inclui-se também como público-alvo e campo de pesquisa para a Pedagogia Social os migrantes e refugiados que chegam à cidade de São Paulo sem falar ou compreender a língua dominante, apartados da cultura local.

Nesse sentido, entendemos que a Pedagogia Social "assume", ainda, papel auxiliar no combate às circunstâncias que afetam negativamente os grupos sociais mais vulneráveis - partindo do princípio de que a sociedade só poderá ser transformada por meio de estratégias educativas que humanizem a pedagogia estritamente escolar e que vejam todos os espaços e relações como essencialmente pedagógicos. 
Dessa forma, ao pensar a Pedagogia Social como a maneira que grupos que foram - e ainda são - marginalizados ao longo da história tiveram acesso à educação, chegar-se-á à conclusão de que ela sempre esteve no cerne da nossa sociedade. De acordo com o professor Roberto da Silva (2016, p. 179), as culturas indígenas, africana e ocidental, juntamente com o cristianismo, compõem a matriz cultural que constitui o Brasil. Em função de o país ter tido, desde sempre, de superar as ideologias que negavam humanidade e conhecimento a gentios, índios e negros, tivemos também que nos ocupar de práticas educativas sociais que constituíram a identidade do povo brasileiro desde o descobrimento do país.

Como enfatiza Roberto da Silva, tais elementos - comuns a diversos povos e países que foram colonizados por nações europeias e cristãs - nos permitiram conceber e construir a educação popular, a educação social e a educação comunitária, que têm uma mesma fundamentação teórica, a Pedagogia Social, e cujo pensador mais proeminente é, sem dúvida, Paulo Freire (SILVA, 2016, p. 179).

No contexto brasileiro atual, a Pedagogia Social tem funcionado como uma ciência prática, social e educativa, não formal, que justifica e compreende, em termos mais amplos, a tarefa da socialização e, em modo particular, a prevenção e a recuperação no âmbito das deficiências da socialização e da falta de satisfação das necessidades fundamentais (SILVA, 2016).

Em relação ao nosso objeto de pesquisa, isso significa que - conforme citamos anteriormente - com a dificuldade de o Estado (em todos os seus níveis federativos) oferecer a todos os migrantes e refugiados oportunidades de aprendizagem da língua portuguesa, as ONGs também têm realizado este trabalho. Nosso interesse é, então, investigar se essas iniciativas - tanto do governo quanto das organizações - possuem fundamentos e práticas da Pedagogia Social e qual a importância que isso assume no processo de socialização dos migrantes e refugiados.

Retomando a assertiva do professor Roberto da Silva, é impossível falar de educação popular ou educação para a transformação da condição de oprimido sem falar de Paulo Freire, que se tornou sinônimo dessa concepção teórica ainda que não tenha sido seu autor original. De acordo com Silva (2016, p. 183), mesmo sem ter escrito especificamente sobre a Pedagogia Social, a influência de Paulo Freire é reconhecida em todo o mundo.

Um dos motivos da Pedagogia Social praticada no Brasil se fundamentar nas ideias de Paulo Freire - e que nos interessa particularmente no estudo de políticas públicas de educação para migrantes e refugiados jovens e adultos - é o fato de que para ele a palavra Pedagogia não significava apenas a educação da criança nas suas formas tradicionais, mas também a elevação do homem adulto ao alto de sua plena humanidade. O professor Roberto da Silva considera a Pedagogia Social não apenas "[...] a educação do indivíduo isolado, mas sim do homem que vive em uma comunidade, porque a sua finalidade não é somente o indivíduo" (2016, p. 185).

Dessa forma, pensar nos direitos educativos de migrantes e refugiados é considerar também as possibilidades que ultrapassam - e que realmente precisam ultrapassar, devido aos tipos de demanda dessa população - a escolarização formal. Temos de pensar que o que está posto, atualmente, nas leis nacionais, para essa população, é "escolarização" e não "Educação"; é a mera execução de medidas que dependem da capacidade de financiamento dos estados nacionais e não das necessidades humanas reais dessa população; é uma educação pautada pela Pedagogia Escolar e pela Educação Escolar, que desconsidera os demais saberes e conhecimentos preexistentes dessa população.

Ainda assim, é direito de migrantes e refugiados ter acesso à escolarização formal - chamada e reconhecida internacionalmente como "direitos educativos" -, a qual também os nacionais estão submetidos. Mas, igualmente, é papel de educadores pensar em uma educação mais abrangente que não exclua o modo de viver e que 
não esteja apartada do processo real de socialização e acolhimento que migrantes e refugiados necessitam nas novas sociedades onde estão inseridos, isto quer dizer, uma educação que não exclua fundamentos da Pedagogia Social.

É, pois, no contexto de vulnerabilidade social (e de necessidade de uma educação que considere suas especificidades e tenha relevância em suas vidas) que a Pedagogia Social e as ideias de Paulo Freire se tornam muito importantes a essa população, sobretudo no ensino da língua portuguesa, a primeira porta para quaisquer outros processos educativos que se seguirão em suas trajetórias nas novas sociedades de acolhimento.

Não é raro perceber que nos mais variados cursos de língua portuguesa oferecidos para migrantes e refugiados - seja iniciativa do Estado ou de Organizações da Sociedade Civil -, além dos instrumentos para lidar com/decifrar o código linguístico, são ofertadas também outras habilidades capazes de ajudá-los em seus processos de socialização e de compreensão da sociedade brasileira. Em última instância, podemos dizer que esse "despertar", essa consciência do ambiente social do país de destino se dá, sobretudo, por meio dos primeiros contatos com a língua local, e se torna uma das chaves - ofertadas pela prática da Pedagogia Social - indispensáveis para a efetivação de direitos e permanência de migrantes e refugiados no território de acolhimento.

De acordo com o pensamento de Paulo Freire, a libertação do oprimido não surge como dádiva da classe dominante, mas como obra construída pelos próprios dominados - a Pedagogia do Oprimido consiste naquela que deve ser elaborada "com eles", e não "para eles". Em um contexto no qual migrantes (sobretudo os econômicos) e refugiados são vistos cada dia mais como perfis indesejados, é peremptório que a educação social lhes sirva de instrumento de luta conjunta por acolhimento digno em qualquer sociedade; de luta pelo reconhecimento de que, originariamente, ninguém tem mais direito do que outro a estar em um determinado lugar da Terra. Sem dúvidas, é por esse motivo - o de dar aos oprimidos uma estratégia social de luta - que encontramos no Brasil uma enorme resistência à teoria do conhecimento formulada por Paulo Freire.

Quando se concebe que a Pedagogia Social está presente nas práticas de educação social e desempenha papel relevante na vida dos migrantes e refugiados que vai além do ensino da língua - embora este seja fundamental para a permanência digna no território de destino e a efetivação de outros direitos fundamentais -, assumese a epistemologia freireana e "[...] seu inconfundível comprometimento com a causa dos 'esfarrapados do mundo' e sua inquebrantável convicção de que a Educação deve libertar não apenas o oprimido, mas também o opressor". Isso porque a natureza da Pedagogia Social é a vocação para "[...] a libertação, a emancipação e a autonomia do sujeito, seja ele oprimido ou opressor" (SILVA, 2016, p. 191).

Ainda no mesmo sentido, quando a importância da Pedagogia Social no ensino de língua portuguesa para migrantes e refugiados é mencionada, revela-se uma prática de educação que também possui "[...] elevada vocação para promover a liberdade, a emancipação e a autonomia do sujeito, rompendo ciclos de marginalização e promovendo rupturas na relação opressor/oprimido" (SILVA et al, 2011, p. 10). Em geral, nas aulas de língua portuguesa para essa população, nota-se um distanciamento da perspectiva essencialmente programática; evidencia-se, ao contrário, uma prática que aspira a criação de condições objetivas e subjetivas que favoreçam o desenvolvimento de habilidades e competências para a vida social.

A constatação de uma prática que direciona não apenas para o aprendizado da língua portuguesa e seus códigos de acesso, mas também para o desenvolvimento de uma consciência crítica e de competências para a vida social, poderá ser mais bem compreendida na parte final deste artigo, principalmente no depoimento da educadora Josefina Lopes Simões, que desenvolveu trabalhos tanto na Missão Paz quanto na E.M.E.F. Infante Dom Henrique, instituição que inspirou a criação do Projeto Portas Abertas, que, por sua vez, também é descrito/caracterizado neste artigo. 
Entendemos a Pedagogia Social como essencialmente importante para o ensino da língua portuguesa para migrantes e refugiados porque, segundo Roberto da Silva (2016, p. 192), suas práticas são "interventivas", ou seja, capazes de promover a garantia e a defesa de direitos a grupos sociais e indivíduos que lutam por um lugar digno em uma estrutura social.

Por fim, entendemos também que as bases freireanas que constituem esse campo do conhecimento se coadunam perfeitamente com o que se espera para a garantia dos direitos educativos de migrantes e refugiados, indo muito além do que - atualmente está posto na lei: o direito a uma teoria e uma prática que possibilitem a transformação a partir dos sujeitos como protagonistas de seu próprio aprendizado; o reconhecimento da legitimidade dos conhecimentos e capacidades que eles já trazem consigo, sejam escolarizados ou não; uma educação que valoriza também os processos, e não apenas os resultados; o equilíbrio entre as aprendizagens formal e não formal; o direito a uma educação que liberta; e, por fim, a consciência de que o direito à educação não é apenas direito de ir à escola, mas o direito de aprender na escola.

2 A Organização Confessional Missão Paz: serviço social e ensino de língua portuguesa

Para descrever e caracterizar a Missão Paz - uma instituição filantrópica, de origem confessional católica, para o apoio e acolhimento de migrantes e refugiados na cidade de São Paulo -, realizou-se uma entrevista com a assistente social Josicleide Barbosa de Souza e foram utilizadas informações disponibilizadas em sua página da internet.

Iniciada em 1939 pelos Missionários de São Carlos, os chamados scalabrinianos - cuja vocação principal consiste em acompanhar e ajudar migrantes e refugiados das mais diversas culturas, crenças e etnias -, atualmente, a Missão Paz é formada por quatro grandes eixos: a Casa do Migrante, o Centro Pastoral e de Mediação dos Migrantes (CPMM), o Centro de Estudos Migratórios (CEM) e a Igreja Nossa Senhora da Paz.

Com quase 90 anos de atuação, a Missão Paz teve de se renovar ao longo de sua história, reestruturando-se a partir dos desafios apresentados pelos diferentes fluxos migratórios. Em meados da década de 2000, por exemplo, as atividades estiveram concentradas, sobretudo, no atendimento de bolivianos que chegavam aos milhares ao Brasil, em condições de extrema vulnerabilidade; entre 2014 e 2015, foram acolhidos ou ajudados pela instituição cerca oito mil haitianos; em 2016, houve uma grande demanda de atendimento a africanos, das mais variadas nacionalidades; e, entre 2017 e 2018, significativo auxílio está sendo prestado à comunidade venezuelana.

A Casa do Migrante é o abrigo da instituição e tem capacidade para acolher 110 indivíduos. Nela, são oferecidos materiais de higiene pessoal, roupas, alimentação e aulas de língua portuguesa, além de acompanhamento de assistentes sociais e apoio psicológico. Além disso, os abrigados podem utilizar seu endereço para recebimento de correspondências. É nesse espaço onde também são realizadas palestras formativas, encaminhamento para cursos profissionalizantes e atividades de lazer.

O Centro de Estudos Migratórios (CEM) constitui o espaço de pesquisas da instituição, com uma biblioteca especializada, que possibilita, ainda, a realização de cursos, seminários e debates sobre as questões acerca da complexa questão migratória. O CEM também edita, desde 1988, a publicação semestral Travessia - Revista do migrante ${ }^{5}$, que é uma importante e reconhecida contribuição interdisciplinar à produção de conhecimento sobre o tema.

Já a igreja Nossa Senhora da Paz acolhe três paróquias: a do bairro do Glicério, a dos italianos e a dos hispano-americanos. Em geral, esses templos são utilizados para as atividades religiosas de diversas comunidades estrangeiras. Embora a Missão Paz seja constituída a partir de uma realidade religiosa, suas atividades fortalecem a

\footnotetext{
5 Números disponíveis para consulta em: <http://revistatravessia.com.br/>. Acesso em: 30 nov. 2018.
} 
abertura ecumênica e inter-religiosa, acolhendo o migrante e refugiado como pessoa e respeitando suas escolhas religiosas e tradições culturais.

Finalmente, o Centro Pastoral e de Mediação dos Migrantes (CPMM) é o local onde acontecem os atendimentos e serviços voltados aos migrantes e refugiados, estruturados nos seguintes temas: "documentação e jurídico"; "saúde"; "serviço social"; "família e comunidade"; "trabalho" e "capacitação e cidadania" - sendo que estes últimos se relacionam diretamente com a presente pesquisa.

No setor de documentação e de assessoramento jurídico, é realizado o serviço de apoio gratuito aos migrantes e refugiados, não somente no tocante à regularização migratória, mas também a outros campos, como direito trabalhista, direito de família, direito previdenciário, naturalização etc.

No eixo família e comunidade, realiza-se o acompanhamento dos núcleos familiares, em especial daqueles que se encontram em situação mais vulnerável, habitando ocupações ou residindo em lugares com condições insalubres. De acordo com a assistente social Josicleide Barbosa de Souza, outra atribuição desse eixo diz respeito à promoção da cultura de não violência doméstica contra as mulheres.

No setor de serviço social ficam concentrados os atendimentos relacionados às demandas espontâneas dos migrantes e refugiados, cabendo à equipe profissional identificar e orientar os casos mais urgentes. Nesse eixo, os atendimentos podem ser feitos individualmente e/ou em grupo socioeducativo, mas sempre visando à emancipação dos sujeitos por meio de uma prática profissional comprometida com a ampliação da cidadania. O eixo saúde tem como foco principal o acompanhamento da saúde física e psíquica dos imigrantes e refugiados, por meio do atendimento/encaminhamento e orientação sobre o acesso e fluxo do Sistema Único de Saúde (SUS).

No entanto, na pesquisa para a elaboração deste artigo - que visa comprovar a presença (e quando possível a importância) da Pedagogia Social nos processos que antecedem a escolarização formal, sobretudo no ensino da língua portuguesa para migrantes e refugiados -, os eixos de atendimento da Missão Paz que mais nos interessam são o de trabalho e capacitação e cidadania. De acordo com Josicleide, atualmente, são eles que proporcionam a mediação para ofertas de trabalho e de aulas de português e o encaminhamento para cursos profissionalizantes.

No primeiro tipo de atendimento citado - a mediação para o trabalho -, existe um processo que visa garantir uma contratação com remuneração justa e condições seguras para migrantes e refugiados.

Em relação ao setor de capacitação e cidadania, o qual está sob responsabilidade de Josicleide, a assistente social explica que ele surgiu a partir da demanda dos próprios migrantes por cursos que os auxiliassem no encaminhamento profissional, possibilitando inserção ao mercado de trabalho. A assistente social esclarece, ainda, que esse eixo de trabalho foi criado para contemplar os jovens e adultos migrantes que precisavam comprovar habilidades e conhecimentos assim que surgiam oportunidades de trabalho. Dessa forma, passou a encaminhar seu público a oportunidades de cursos profissionalizantes ou universitários. Além disso, decidiu ofertar aulas de língua portuguesa nas próprias dependências da Missão Paz. Tais atividades tiveram início a partir de 2014, durante o atendimento ao grande número de haitianos que chegavam à Missão Paz em busca de ajuda. Depois, com a continuidade da demanda, inclusive por migrantes e refugiados de outras nacionalidades, o projeto teve sua proposta ampliada e estendida a todos os interessados.

Atualmente, as aulas de língua portuguesa oferecidas pela Missão Paz têm supervisão da professora Rosane de Sá Amado, doutora em linguística e docente da Universidade de São Paulo (USP). De acordo com Josicleide, mesmo não havendo uma parceria institucional formalizada com a USP, a professora Rosane de Sá Amado tem incentivado, ao longo dos anos, seus alunos a fazerem parte do quadro de professores 
voluntários no ensino de língua portuguesa para estrangeiros. Esse incentivo foi tão expressivo que, durante um período, a professora Rosane conseguiu transformar trabalho voluntário em um projeto consistente de pesquisa por meio do programa Aprender com Cultura e Extensão, da Universidade de São Paulo. Dessa forma, alguns de seus alunos tiveram - durante um tempo - uma bolsa para atuar como professores de língua portuguesa para estrangeiros, tanto Centro de Línguas da USP quanto na atuação em Instituições como a Missão Paz.

Josicleide salientou ainda que Rosane, voluntária do projeto há alguns anos, sistematizou sua prática pedagógica ao elaborar um material de trabalho que é exclusivo da instituição e específico para o ensino da língua portuguesa como processo de acolhimento.

As aulas acontecem na Missão Paz, de segunda à sexta, das 9h às $12 \mathrm{~h}$. Além dos educadores voluntários que vêm por meio da professora Rosane, há outros que, para atuar no projeto, precisam atender aos seguintes requisitos: ter formação acadêmica em qualquer área e, se possível, conhecimentos em línguas mediadoras, tais como francês, inglês, espanhol ou árabe. Os horários de participação em sala de aula são flexíveis.

Rosane entende que a população migrante enfrenta muitas barreiras para se integrar nas sociedades em que chegam, a começar pelos obstáculos linguísticos, de sons e escrita insólitos para a maioria: "[...] muitas famílias sírias, por exemplo, desembarcam apenas com as mochilas, sem saber falar nada de português. Os funcionários do aeroporto ligam para alguma ONG avisando para ir buscá-las" (HONORATO, 2017, s.p.).

Na Missão Paz, e na contramão do preconceito, Rosane - bem como os outros professores que atuam como voluntários no local - age, em sala de aula, como anfitriã, compartilhando impressões culturais com os alunos e indagando sobre as peculiaridades de suas línguas maternas: "[...] tento trabalhar com eles a interculturalidade voltada às línguas [...] Pergunto a respeito das impressões antes e depois de chegar ao Brasil e também falamos deles. Conversamos sobre o que trazem de sua cultura, não sobre os aspectos trágicos da imigração" (HONORATO, 2017, s.p.).

A abordagem da professora Rosane - adotada pelos outros educadores da Missão Paz - nos remete à Pedagogia Social, pois, ainda que o curso ofertado na instituição cumpra com algumas especificações formais de ensino-aprendizagem, ele não almeja apenas decifrar os códigos da língua portuguesa; ela busca retirar os migrantes de uma condição desumana que a própria migração lhes infringe: "Garantir aos estrangeiros pelo menos o mínimo de comunicação na língua portuguesa faz parte de uma recepção humanitária" (HONORATO, 2017, s.p.). A professora ainda menciona os desafios para a implementação de uma política linguística de acolhimento aos estrangeiros e refugiados: "[...] faltam professores, a evasão dos alunos é grande e as iniciativas na área ainda são descoordenadas e predominantemente do terceiro setor. Mas nada disso deve nos assustar" (HONORATO, 2017, s.p.).

Por fim, Rosane ressalva que o papel de voluntários não docentes ministrando português para migrantes e refugiados é essencial em caráter emergencial, mas que é inconcebível em um país como o Brasil, com mais de 400 cursos de Letras, formando mais de 30 mil professores por ano, não ter ainda um programa consistente que contrate professores, mesmo sem formação inicial em "Português como língua estrangeira", para o ensino de português como língua de acolhimento para migrantes e refugiados (AMADO, 2014, s.p.).

Voltando ao atendimento prestado especificamente na Missão Paz, de acordo com a assistente social Josicleide, apesar de todos os cuidados que a instituição dedica aos migrantes e refugiados, ofertando o curso sempre respeitando as características e especificidades dos atendidos, existem dificuldades pontuais a serem superadas, como a grande evasão (principalmente dos alunos que encontram emprego e precisam priorizar 
a atividade remunerada) e a baixa adesão das mulheres sírias, que não frequentam as aulas por conta da religião e da cultura.

Ao analisar o relato da assistente social Rosicleide, chegamos à conclusão de que o ensino de língua portuguesa da Missão Paz, ofertado em uma instituição confessional católica, é marcado pela presença de muitas características da Pedagogia Social e suas práxis. Dar aos migrantes e refugiados ferramentas para que eles saiam da indigência social (não saber ler, escrever ou falar uma língua dominante em uma sociedade grafocêntrica é permanecer marginalizado), mas para que também possam procurar emprego digno e atuar na efetivação de seus outros direitos humanos é utilizar as importantes bases da Pedagogia Social, sobretudo as freireanas, em seu processo de socialização.

A constatação final de que a iniciativa da Missão Paz possui pressupostos da Pedagogia Social está no fato de que suas ações para o Ensino de Língua Portuguesa estão pautadas em domínios específicos desse campo da ciência: o domínio sociopedagógico (aquele que garante uma intervenção cujo objetivo principal é atuar no desenvolvimento de habilidades e competências sociais que permitam aos usuários romper e superar as condições de marginalidade, violência e pobreza que caracterizam sua exclusão social) e o domínio sociopolítico (que visa o conhecimento dos processos sociais e políticos, das formas de participação, de protagonismo, de associativismo, de cooperativismo, de empreendedorismo, de geração de renda e de gestão social). Como constatamos nas práticas observadas e como assevera o professor Roberto da Silva, as ações pedagógicas dos domínios sociopedagógico e sociopolítico têm como objetivo "[...] o desenvolvimento de habilidades e competências para qualificar a participação na vida social, política e econômica da comunidade onde o sujeito está inserido ou dos espaços onde a pessoa queira estar como sujeito" (SILVA et al, 2011, p. 7).

\section{Programa municipal Portas Abertas: língua portuguesa nas escolas da rede}

As informações utilizadas para a descrição/caracterização do projeto Portas Abertas: português para imigrantes foram retiradas, sobretudo, de sua página na internet, e também do depoimento de Josefina Lopes Simões, educadora que desempenhou trabalhos na Missão Paz e na E.M.E.F. Infante Dom Henrique, a escola que inspirou a criação do programa municipal.

Iniciativa conjunta da Secretaria Municipal de Direitos Humanos e Cidadania (SMDHC) e da Secretaria Municipal de Educação (SME), o projeto Portas Abertas objetiva, em termos gerais, oferecer curso de português gratuito, contínuo e permanente dentro da estrutura física e por meio dos recursos humanos da Rede de Municipal de Ensino (RME) para alunos migrantes e refugiados, suas famílias e comunidades.

Entre os seus objetivos específicos, no entanto, estão o compromisso de fomentar a autonomia e a capacitação profissional; garantir o respeito à diversidade e à interculturalidade; promover a integração local dos migrantes; e, sobretudo, incentivar a cidadania por meio do aprimoramento de técnicas de leitura, escrita, escuta e fala da língua portuguesa, adotando metodologias que dialoguem com as situações cotidianas dos migrantes e refugiados.

A idealização do projeto surgiu das demandas históricas das populações migrantes que habitam a cidade de São Paulo e se baseou no compromisso da implementação da Política Municipal para População Imigrante de São Paulo, a partir da Lei n 16.478/2016 e do Decreto $n^{\circ} 57.533 / 2016$, já citados neste trabalho.

Então, por meio da Portaria Intersecretarial $n^{\circ} 002 / 2017^{6}$, foi instituído o programa Portas Abertas, cuja normativa reconheceu como público-alvo toda pessoa que se transfere de seu lugar habitual de residência para outro país, compreendendo os migrantes laborais, as pessoas em situação de refúgio, os portadores de visto

\footnotetext{
Portaria Intersecretarial SMDHC/SME $n^{\circ}$ 002, de 18 de agosto de 2017. Disponível em: <www.prefeitura.sp.gov.br/cidade/ secretarias/direitos_humanos/migrantes/programas_e_projetos/portas_abertas/index.php?p=259304>. Acesso em: 25 nov. 2018.
}

Cad. Pesq., São Luís, v. 26, n. 2, p. 107-127, abr./jun., 2019. 
humanitário, os estudantes, os apátridas, bem como suas famílias, independentemente de sua situação migratória ou documental. A Portaria também definiu como ações importantes o combate à xenofobia e a incorporação da temática migratória e ações voltadas ao acolhimento e à garantia de acesso, permanência e aprendizagem da população imigrante aos projetos político-pedagógicos das unidades educacionais da Rede Municipal de Ensino.

Por se tratar de um Projeto Intersecretarial, seus principais atores - órgãos da Prefeitura - possuem responsabilidades e atribuições específicas. Conjuntamente, as duas pastas respondem às obrigações de elaborar e ofertar formação inicial e continuada aos profissionais da Rede Municipal de Ensino interessados em atuar no Projeto, por meio de Acordos de Cooperação da SMDHC com o Centro de Línguas da FFLCH-USP; promover sua divulgação, especialmente para o público-alvo; e formular os instrumentais para a inscrição e a coleta de dados dos participantes do Projeto, a fim de realizar o seu acompanhamento contínuo em termos quantitativos e qualitativos.

Ainda de acordo com as especificações da Portaria, o projeto Portas Abertas será realizado em Unidades Educacionais da Rede Municipal de Ensino de São Paulo que serão convidadas pela SME, estabelecidas em áreas com significativa concentração de população migrante, e mediante concordância da Equipe Gestora para a sua inclusão no projeto político-pedagógico.

Cada unidade escolar que desejar participar deverá formalizar a incorporação a esta política mediante a elaboração de um Projeto Pedagógico que visa conter a justificativa, os objetivos, a metodologia, carga horária, cronograma das turmas, recursos materiais e humanos, prevenção trimestral de gastos, formas de avaliação, referências bibliográficas, aprovação do Conselho da Escola, parecer da Equipe Técnica, manifestação do Supervisor Escolar e homologação do Diretor Regional de Educação - a lista de pré-requisitos é grande.

Atualmente, o curso de língua portuguesa do Portas Abertas está organizado da seguinte maneira: turmas nos níveis básico, intermediário e avançado, sendo que cada nível deverá ser constituído por 90 (noventa) horas-aula de 45 (quarenta e cinco) minutos cada, distribuídas em um semestre letivo. Os encontros são realizados 2 (duas) vezes por semana, preferencialmente no período noturno, com 3 (três) horas-aula de duração cada. As turmas deverão ter entre 15 e 25 alunos, no máximo, independentemente de sua nacionalidade - o que significa alunos fluentes em diversas línguas, como o francês, espanhol, inglês, árabe, crioulo haitiano etc. As inscrições dos migrantes e refugiados deverão ocorrer nas próprias Unidades Educacionais em que acontecem os cursos, de acordo com o número de vagas disponíveis, independentemente de sua situação imigratória e documental ou de sua nacionalidade.

Os inscritos deverão realizar uma avaliação diagnóstica sobre o seu domínio da língua portuguesa, a partir da qual serão classificados - conforme análise dos professores envolvidos no Projeto e da Equipe Gestora - em um dos três níveis previstos (básico, intermediário e avançado).

Os interessados podem se inscrever em qualquer momento do semestre letivo no ato da matrícula, é fornecida ao aluno uma ficha de inscrição, em português, com tradução para o espanhol, inglês e francês. No entanto, para obter o certificado de cada módulo, é necessário que os alunos tenham comparecido a ao menos $75 \%$ das aulas durante o semestre. A certificação será concedida conjuntamente pela Secretaria Municipal de Direitos Humanos e Cidadania, pela Secretaria Municipal de Educação e pelo Centro de Línguas da Faculdade de Filosofia, Letras e Ciências Humanas da Universidade de São Paulo.

As aulas são ministradas por professores da Rede Municipal de Ensino que participaram de formação promovida por meio de parceria entre a SME, SMDHC e o Centro de Línguas do Departamento de Filosofia, Letras e Ciências Humanas da Universidade de São Paulo e do Projeto de Extensão MemoRef, da Universidade 
Federal de São Paulo. O processo de capacitação técnica dos docentes também dispõe da participação do Centro de Referência e Atendimento para Imigrantes (CRAI) para tratar de assuntos migratórios, o contexto da imigração em São Paulo, a garantia de direitos dos imigrantes e seu acesso a serviços.

$\mathrm{Na}$ referida Portaria de criação do projeto há especificações de como serão realizadas as seleções dos professores: a indicação de interessados será realizada a cada semestre ou, quando necessário, pela Equipe Gestora de cada Unidade Educacional onde o Projeto será desenvolvido.

Os requisitos para trabalhar no projeto são: ser professor efetivo da Rede Municipal de Ensino, preferencialmente ocupante do cargo de Professor de Ensino Fundamental Il e Médio - Português e ter realizado e concluído curso específico sobre o ensino da língua portuguesa para migrantes oferecido pela SME e pela SMDHC. A remuneração dos profissionais acontecerá a título de Jornada Especial de Horas-Trabalho Excedente (TEX), nos termos da Lei Municipal $n^{\circ} 14.660 / 07$, respeitados os limites estabelecidos na legislação vigente. Em 2018, as aulas ocorreram em doze unidades escolares ${ }^{7}$, distribuídas pelas zonas norte, sul e leste da cidade.

A metodologia utilizada conta com aulas expositivas e interativas que devem enfatizar o uso funcional do português em situações do cotidiano e que abordem, inclusive, discussões e reflexões relevantes ao público em questão. As aulas promovem o desenvolvimento da comunicação oral, bem como da compreensão auditiva e da escrita, com o auxílio de material de apoio e de recursos multimídia.

O curso conta ainda com material didático próprio. É importante indicar aqui que tal material - Portas Abertas: Português para Imigrantes ${ }^{8}$ - é uma realização conjunta entre a Secretaria Municipal de Direitos Humanos e Cidadania e o Centro de Línguas da USP, mediante acordo de cooperação técnica, contando também com a participação ativa da já citada Profa. Dra. Rosane Amado de Sá.

No caso, o conteúdo didático foi elaborado por ela, em parceria com as Professoras Marina Reinoldes e Paola Mandalá, e traz como metodologia pioneira o ensino da língua portuguesa como ferramenta de acolhimento e garantia de direitos para a população imigrante.

De acordo com as autoras, a produção do material, de fato, só foi possível graças à equipe de monitoras bolsistas do programa Aprender com Cultura e Extensão, da Universidade de São Paulo (também já cita neste artigo), coordenada pela Professora Rosane de Sá Amado; ao grupo de professores voluntários que atuam nos cursos de português para migrantes da Missão Paz, da Escola Infante Dom Henrique e do Centro de Línguas da USP, orientado pela Professora Paola de Souza Mandalá, da Faculdade de Filosofia, Letras e Ciências Humanas, da Universidade de São Paulo; e aos estudantes de graduação da UNIFESP, monitores no Projeto de Extensão MemoRef, de língua e cultura brasileira para refugiados (REINOLDES et al, 2017, p. 3).

Na apresentação do material, as autoras reafirmam a importância de compreender a língua dominante nas sociedades de acolhimento. Segundo elas, todos devem se preocupar com a questão - tanto os migrantes como aqueles que os recebem. É por esse motivo que diversos grupos têm se organizado para oferecer cursos de português para migrantes e refugiados, os quais precisam, com rapidez, se capacitar linguisticamente não só para a expressão cotidiana, mas também para as questões formais de documentação, trabalho e garantia de direitos (REINOLDES et al, 2017, p. 3).

\footnotetext{
Para ter acesso completo às escolas que ofereceram curso de língua portuguesa para migrantes e refugiados por meio do Portas Abertas, é preciso acessar a página do projeto. Disponível em: <www.prefeitura.sp.gov.br/cidade/secretarias/direitos_humanos/migrantes/ programas_e_projetos/portas_abertas/index.php?p=259375> Acesso em: 25 nov. 2018.

8 O material Portas Abertas: Português para Imigrantes está disponível em: <www.prefeitura.sp.gov.br/cidade/secretarias/direitos_humanos/ migrantes/programas_e_projetos/portas_abertas/index.php?p=259310> Acesso em: 25 nov. 2018.
} 
Dessa forma, o material didático específico é a parte do Projeto que pode ser melhor relacionada com os pressupostos da Pedagogia Social, pois trata o Português, de fato, como Língua de Acolhimento e contribui não apenas para a capacitação linguística, mas, sobretudo, para um aprendizado trilhado pelo caminho do esclarecimento dos Direitos dos Migrantes, pelo domínio e conhecimento do espaço geográfico, pelo conhecimento das características sociopolíticas do país, pela inserção digna na sociedade e no trabalho e pela troca intercultural (REINOLDES et al, 2017, p. 3).

$\mathrm{Na}$ análise das diretrizes gerais do projeto, percebe-se que se trata de iniciativa muito relevante, e que o município de São Paulo tenta, com isso, suprir uma necessidade primordial dos migrantes e refugiados que chegam à cidade e cumprir um papel que é, em primeiro lugar, função do Estado. No entanto, é evidente também que a sua organização ainda está mais pautada nas práticas formais de escolarização que nos fundamentos da Pedagogia Social.

No entanto, mesmo que tais práticas formais - que pressupõem quase sempre um processo de "escolarização", e não de "educação" - estejam presentes na sua organização, como o teste de nivelamento na hora da inscrição, a obrigatoriedade de $75 \%$ de presença para a certificação, e a utilização de espaço estritamente escolar para a realização das aulas, existem características no Projeto que nos permitem classificá-lo também dentro das práticas da educação social, popular e comunitária, como a necessidade de capacitação dos docentes sobre a questão migratória e o seu já citado material didático, elaborado por educadoras que já trabalham - no âmbito da práxis, no voluntariado, e no âmbito epistemológico, das pesquisas acadêmicas - com esse público. Podemos concluir que essas características do Projeto Portas Abertas se coadunam com os princípios da Pedagogia Social principalmente por ter práticas educativas como a própria essência das relações do ser humano; ter uma prática que não deve se subordinar a determinações político-ideológicas, doutrinárias ou dogmáticas, mas se centrar nas necessidades dos atendidos; ter a História, a Cultura, e o acesso aos Direitos como categorias orientadoras das ações pedagógico-sociais que garantem ao projeto Portas Abertas um equilíbrio entre as aprendizagens formal e não formal e a já citada consciência de que o direito à educação não é apenas direito de ir à escola, mas o direito de aprender na escola.

\section{Depoimento sobre trabalhos desenvolvidos na Missão Paz e na EMEF Infante Dom Henrique}

A seguir, um depoimento realizado a partir de encontro com Josefina Lopes Simões, a educadora que desempenhou trabalhos voluntários na Missão Paz e na E.M.E.F. Infante Dom Henrique, a escola que inspirou a criação do projeto Portas Abertas com o seu "Curso de Português para Estrangeiros", por meio do qual percebemos a importância da Pedagogia Social nos serviços prestados para a garantia de direitos educativos de migrantes e refugiados tanto no âmbito do Estado quanto das Organizações da Sociedade Civil.

"A Escola Municipal de Ensino Fundamental Infante Dom Henrique está localizada no bairro do Canindé, entre a região central e a zona Leste da cidade, próxima ao Brás, principal centro têxtil da cidade. Repleta de confecções onde trabalham pessoas de diversas nacionalidades, especialmente bolivianos, a região tem muitos sobrados antigos, que, transformados em cortiços, são onde residem um grande número de migrantes. A região também possui alguns centros de acolhida para moradores de rua, pequenas comunidades e uma 'Casa do Imigrante'. Dessa forma, a área é povoada por pessoas de baixa renda, resultando na alta frequência de crianças e adolescentes, filhos de refugiados e migrantes, nesta instituição escolar.

Por conta da demanda deste público, o diretor - Claudio Neto - vem trabalhando a questão do acolhimento de migrantes e refugiados desde 2015 . O primeiro problema encontrado na escola foi o bullying, praticado entre os alunos. Daí surgiu a necessidade 
de um projeto interno para a melhoria da convivência entre alunos migrantes e brasileiros, sobretudo quando muitos deles ainda não falavam a língua Portuguesa.

O diretor buscou ajuda de especialistas, inclusive no Centro de Línguas da USP; organizou reuniões com os professores e funcionários da escola; acolheu voluntários e juntou a comunidade para discutir e planejar um ensino que abordasse práticas de acolhimento, bem como desenvolvesse e permitisse que os alunos vivenciassem um ambiente escolar seguro e inclusivo.

No primeiro semestre de 2016, o diretor iniciou um projeto de ensino de Português para migrantes juntamente com uma voluntária do Centro de Línguas e alunos da pósgraduação da Faculdade de Letras, Filosofia e Ciências Sociais da USP (FFLCH) - na época, muitos pais imigrantes e refugiados procuravam a escola buscando informações sobre cursos de língua Portuguesa. Devido à demanda do público, no meio do ano de 2016, a escola recebeu um projeto de aulas de Português para adultos, fruto de uma parceria entre a Prefeitura de São Paulo, por meio das Secretarias Municipais de Direitos Humanos e Cidadania (SMDHC) e de Educação (SME), com o Ministério da Justiça, o Comitê Nacional para Refugiados (Conare) e o Instituto Federal do Sul de Minas (por meio do PRONATEC - Programa Nacional de Acesso ao Ensino Técnico e Emprego). Nesses moldes, o projeto ficou na escola por um curto período de tempo: cerca de seis meses. $O$ curso acontecia à noite, com carga horária de 12 horas semanais, de terçafeira a sexta-feira, das $19 \mathrm{~h}$ às $22 \mathrm{~h}$ horas e os seus alunos ganhavam 10 reais por dia de aula; ao final, recebiam um certificado federal conclusão do curso.

Com os problemas políticos na conjuntura do país, o programa foi retirado da escola. No entanto, o número de interessados procurando o curso de Português continuava crescendo. Então, na época, o diretor e a professora do programa - que perdeu todos os seus direitos trabalhistas, como salário e transporte - decidiram continuar com as aulas, em um projeto voluntário. Foi nesta ocasião em que fui convidada a participar da ação.

A minha experiência na escola mostrou que existe, de fato, novos fluxos migratórios - os alunos vinham de muitos países diferentes: em sua maioria sírios, bengaleses, congoleses, nigerianos, angolanos, palestinos, paquistaneses, bolivianos, peruanos, cubanos, e outros mais. Mas me mostrou também que a partir de algumas práticas da educação social é possível realizar um trabalho que dá resultados. Mesmo com poucos recursos, estávamos tentando, diariamente, mudar a condição de vida desses homens e mulheres deslocados a partir da educação social. A coordenação da escola nos apoiava fornecendo o local, mas, muitas vezes, não tínhamos recursos para materiais básicos como caderno, borracha, caneta e lápis. No entanto, junto com os atendidos, realizávamos campanha para conseguir o que nos faltava.

O material didático que utilizávamos foi produzido pela equipe da professora Rosane de Sá Amado para ser testado por meio deste projeto. Posteriormente, o material foi aprimorado e se tornou o apoio oficial do Projeto Portas Abertas, da prefeitura.

Também era um desafio dar aulas para grupos tão diferentes em termos de cultura; era possível encontrar alunos falantes de línguas que não possuem familiaridade alguma com as línguas latinas, como o caso do Bengali e do Lingala. Por isso, era necessário um material didático que permitisse aos alunos se perceber e se imaginar em situações reais de uso da língua -, mas isso a todos os alunos (com suas diversas nacionalidades e especificidades); um material que garantisse o aprendizado dos direitos básicos dos migrantes e refugiados e que fosse utilizado dentro dessa concepção.

Outro desafio a ser encarado era a necessidade de considerar fatores como a cultura de aprendizado de cada aluno, além da idade do público, pois era normal encontrar em uma classe alunos entre dezoito e sessenta anos, com níveis escolares muito diferentes. Sem contar a presença de um público flutuante, pois os alunos que aprendiam mais rápido - e assim se inseriam na sociedade por meio do emprego, 
de curso profissionalizante ou da mudança de endereço (para aqueles que viviam em abrigos) - desistiam do curso ou faltavam bastante.

No segundo semestre de 2017, a prefeitura de São Paulo realizou uma parceria entre a Secretaria Municipal de Educação (SME) e a Secretaria Municipal de Direitos Humanos e Cidadania (SMDHC) e o Centro de Línguas da USP com o objetivo de oferecer o ensino da língua portuguesa na Rede Municipal de Ensino na cidade de São Paulo - o Projeto Portas Abertas. Na ocasião, a EMEF Infante Dom Henrique, por já apresentar um trabalho consistente na temática desde 2015, foi escolhida como referência e como uma das escolas pilotos do projeto, chegando a ter seu nome divulgado pela prefeitura.

Graças ao desenvolvimento de ações para promover o respeito à diversidade e a integração dos seus alunos estrangeiros, tais como realizar toda a comunicação visual interna em quatro idiomas (português, espanhol, árabe e inglês), a escola já recebeu premiações e até convite da Unesco para participar de um programa mundial de escolas associadas.

No entanto, a escola nunca entrou oficialmente no âmbito do projeto da prefeitura, que, aliás, fornece lanche e material gratuito para os alunos. Embora, tenha ocorrido a divulgação do nome da EMEF Infante Dom Henrique no programa - e de as turmas já existirem no local, em atividade anterior -, a prefeitura nunca enviou o material didático, assim como não aconteceu de nenhum professor da rede ter se oferecido para participar do projeto na instituição, prosseguindo desta maneira como uma iniciativa popular e comunitária.

No ano de 2018, continuamos com o projeto, de forma independente do Programa Portas Abertas. Este ano, apesar de não termos ajuda estruturada, mas apenas o trabalho conjunto entre escola, voluntários e migrantes, iniciamos com condições mais favoráveis: foi organizada a divulgação do curso de maneira prévia e mais professores se ofereceram como voluntários. Nós também conseguimos arrecadar material escolar, como lápis, caneta, cadernos e borrachas para os alunos e doações para a confecção de cópias do livro didático do Portas Abertas.

Em relação à Missão Paz, eu conheci instituição em 2015, quando iniciei o trabalho voluntário de aulas para migrantes. Na época, eu trabalhava em outra ONG e fui participar de um curso de formação de professores na instituição. Logo depois, fui chamada para trabalhar como professora voluntária na Missão Paz. Porém, como eu já tinha meus alunos na outra instituição, decidi não ir para lá nessa ocasião. Em 2017, ao começar meu trabalho como professora voluntária na E.M.E.F. Infante Dom Henrique - concomitantemente ao trabalho de ministrar aulas especificas para mulheres deslocadas dentro da Casa do Migrante -, percebi, na ocasião, que o segundo trabalho teria muitos obstáculos, pois as mulheres têm dificuldades para participar das aulas devido aos filhos e, em alguns casos, como as sírias, por questões culturais. Como este trabalho não deu certo por conta das regras rígidas dos abrigos de acolhimento, eu desisti e, finalmente, comecei a ministrar aulas na Missão Paz, no segundo semestre de 2018.

A Missão paz é uma instituição dentro da congregação Scalabriana da igreja católica. O local é um complexo grande, onde funcionam diversos departamentos. Existe uma demanda muito grande, com alunos de diversas nacionalidades. As turmas também são mistas, tanto em relação a gênero e idade, quanto em relação ao nível dos alunos. Embora a Missão Paz não receba ajuda do governo para o atendimento dessa população em relação à língua portuguesa, o local possui um pouco mais de estrutura, fornecendo material didático para os alunos, por exemplo. Por conta do tempo de voluntariado na Missão Paz - ainda diminuto em relação ao tempo em que sou voluntária na EMEF -, minhas impressões em relação a esta instituição ainda estão em processo maturidade, mas posso adiantar que gosto muito de atuar na instituição, sobretudo, por conta da boa vontade de todos os envolvidos. 


\section{A nosso pedido, Josefina Lopes Simões preencheu um quadro comparativo sobre os aspectos que consideramos mais relevantes nas duas linhas de ensino de Português para migrantes e refugiados com as quais ela teve contato e que analisamos neste artigo.}

Quadro 1. Comparação sobre aspectos relevantes nos curso de ensino de Língua Portuguesa da Missão Paz e da EMEF Henrique Dom Infante.

\begin{tabular}{|c|c|c|}
\hline & MISSÃO PAZ & $\begin{array}{l}\text { CURSO DE PORTUGUÊS PARA MIGRANTES - EMEF } \\
\text { HENRIQUE DOM INFANTE (Inspiração para o Projeto } \\
\text { Portas Abertas da Prefeitura de São Paulo) }\end{array}$ \\
\hline Público-alvo & Migrantes diversos e refugiados. & Migrantes diversos e refugiados. \\
\hline $\begin{array}{l}\text { Processo de matrícula } \\
\text { (sobre exigência de } \\
\text { documentação) }\end{array}$ & $\begin{array}{l}\text { Devido à grande demanda de público, a Missão } \\
\text { Paz tem um sistema de regras com o intuito de au- } \\
\text { xiliar a Instituição. } \\
\text { Lá, existe o setor de "cursos e capacitações" que } \\
\text { realiza a matrícula dos alunos. Pode-se fazer a } \\
\text { matrícula com o protocolo de solicitação de refúgio } \\
\text { ou de documentos na Polícia federal ou qualquer } \\
\text { documento de identificação. }\end{array}$ & $\begin{array}{l}\text { A matrícula é realizada na própria escola. Também é pos- } \\
\text { sível fazer a matrícula com protocolos ou qualquer docu- } \\
\text { mento de identificação. }\end{array}$ \\
\hline $\begin{array}{l}\text { Tratamento das } \\
\text { questões de gênero, } \\
\text { nacionalidade, cultura } \\
\text { ou religião }\end{array}$ & $\begin{array}{l}\text { As classes são mistas. O público é diversificado } \\
\text { com relação à nacionalidade, idade, cultura e gêne- } \\
\text { ro. Alunos homens são a maioria; grande números } \\
\text { de Haitianos, Venezuelanos e Cubanos. Algumas } \\
\text { mulheres assistem aula com os bebês no colo. } \\
\text { Também encontramos diversidade em relação à } \\
\text { escolaridade, pois percebemos alunos com muita } \\
\text { dificuldade até mesmo para escrever tendo aulas } \\
\text { junto com alunos que já realizaram mestrado. To- } \\
\text { dos são atendidos da mesma maneira e com os } \\
\text { mesmos direitos. }\end{array}$ & $\begin{array}{l}\text { As classes são mistas. O público é diversificado, com } \\
\text { relação à nacionalidade, idade, cultura e gênero. Alunos } \\
\text { homens são a maioria; grande números de paquistaneses, } \\
\text { bengaleses, sírios, haitianos, peruanos, bolivianos e nige- } \\
\text { rianos. Apenas } 2 \text { mulheres assistem à aula neste semestre } \\
\text { (segundo semestre de 2018). Também encontramos diver- } \\
\text { sidade em relação à escolaridade, pois alunos com mui- } \\
\text { tas dificuldades em salas em salas com alunos altamente } \\
\text { escolarizados. Todos são atendidos da mesma maneira e } \\
\text { com os mesmos direitos. }\end{array}$ \\
\hline $\begin{array}{l}\text { Tratamento dado a } \\
\text { migrantes e refugiados } \\
\text { (alguma distinção?) }\end{array}$ & $\begin{array}{l}\text { Tratamento igual para todos os migrantes, inde- } \\
\text { pendentemente da sua situação ou categoria mi- } \\
\text { gratória. }\end{array}$ & $\begin{array}{l}\text { Tratamento igual para todos os migrantes, independente- } \\
\text { mente da sua situação ou categoria migratória. }\end{array}$ \\
\hline $\begin{array}{l}\text { Estrutura (espaço, } \\
\text { salas de aulas, recur- } \\
\text { sos físicos) }\end{array}$ & $\begin{array}{l}\text { A Missão Paz possui espaço para duas salas de } \\
\text { aula. Disponibiliza giz, quadro negro para os pro- } \\
\text { fessores. Além disso, consegue materiais para os } \\
\text { alunos. }\end{array}$ & $\begin{array}{l}\text { A E.M.E.F. Infante Dom Henrique fornece a estrutura como } \\
\text { a sala de aula para o projeto e organização de matrícula. } \\
\text { O material utilizado na sala de aula vem de iniciativa dos } \\
\text { professores que organizam vaquinhas e pequenas cam- } \\
\text { panhas para arrecadação de material e cópias de livros. }\end{array}$ \\
\hline $\begin{array}{l}\text { Material didático (que } \\
\text { tipo de material tem } \\
\text { disponível?) }\end{array}$ & $\begin{array}{l}\text { Apostila própria da Missão Paz desenvolvida pela } \\
\text { Professora Dra. Rosane de Sá Amado e colabora- } \\
\text { dores. }\end{array}$ & $\begin{array}{l}\text { Apostila do Projeto Portas Abertas, da Prefeitura, também } \\
\text { desenvolvido com parceria da Professora Dra. Rosane de } \\
\text { Sá Amado. }\end{array}$ \\
\hline $\begin{array}{l}\text { Qualidade do Material } \\
\text { didático (cartilha) }\end{array}$ & $\begin{array}{l}\text { O material foca principalmente na comunicação } \\
\text { oral e na aquisição da língua para a garantia de } \\
\text { direitos; as cópias são em preto e branco. }\end{array}$ & $\begin{array}{l}\text { O material foca principalmente na comunicação oral; na } \\
\text { aquisição da língua para a garantia de direitos e no Por- } \\
\text { tuguês como língua de acolhimento. Recebemos doações } \\
\text { de cópias em preto e branco de amigos professores. }\end{array}$ \\
\hline $\begin{array}{l}\text { Estrutura das aulas } \\
\text { (carga horária, crono- } \\
\text { grama) }\end{array}$ & $\begin{array}{l}\text { Curso intensivo, dividido em módulos: básico } 1 \text { e } \\
\text { básico 2, com duração de um mês cada. As aulas } \\
\text { acontecem diariamente com duração de até } 3 \text { ho- } \\
\text { ras. As turmas são fechadas, ou seja, alunos novos } \\
\text { não entram durante o curso. }\end{array}$ & $\begin{array}{l}\text { Curso semestral, dividido em módulos: básico } 1 \text { e básico } \\
\text { 2. As aulas acontecem diariamente com duração de } 1 \text { hora } \\
\text { e trinta minutos para cada módulo. A turma é aberta e os } \\
\text { alunos podem entrar na classe em qualquer período do } \\
\text { ano, no entanto, os estudantes apenas ganham certificado } \\
\text { se possuírem } 75 \% \text { de frequência. }\end{array}$ \\
\hline $\begin{array}{l}\text { Regime de contratação } \\
\text { dos professores }\end{array}$ & $\begin{array}{l}\text { Trabalho voluntário com termo de voluntariado as- } \\
\text { sinado. }\end{array}$ & Trabalho voluntário com termo de voluntariado assinado. \\
\hline $\begin{array}{l}\text { Forma de pagamento } \\
\text { ou recompensa para o } \\
\text { professor }\end{array}$ & O professor não recebe nenhum valor pelas aulas. & O professor não recebe nenhum valor pelas aulas. \\
\hline $\begin{array}{l}\text { Autonomia dos profes- } \\
\text { sores em sala de aula }\end{array}$ & $\begin{array}{l}\text { A regra é que o professor precisa dar o conteúdo } \\
\text { da apostila, ficando livre para utilizar material extra } \\
\text { se achar necessário. Qualquer custo extra é pago } \\
\text { pelo professor. }\end{array}$ & $\begin{array}{l}\text { O professor é livre para planejar a aula. Ele não precisa } \\
\text { necessariamente seguir a cartilha do Portas Abertas, mas } \\
\text { no começo do semestre conversamos sobre como segui- } \\
\text { remos os conteúdos propostos. }\end{array}$ \\
\hline
\end{tabular}




\begin{tabular}{|c|c|c|}
\hline $\begin{array}{l}\text { Gestão democrática } \\
\text { (participação dos pro- } \\
\text { fessores e dos alunos } \\
\text { na estruturação do } \\
\text { curso) }\end{array}$ & $\begin{array}{l}\text { A Missão Paz estabelece como regra reuniões pe- } \\
\text { dagógicas, uma vez por mês com os professores. } \\
\text { As reuniões englobam temas que fazem parte do } \\
\text { cotidiano dos alunos e também serve para con- } \\
\text { versamos sobre situações que ocorrem em cada } \\
\text { curso. }\end{array}$ & $\begin{array}{l}\text { Na E.M.E.F Infante Dom Henrique, as reuniões acontecem } \\
\text { semestralmente. Como o número de voluntários é peque- } \\
\text { no, devido à localização da escola, e o curso ser noturno, } \\
\text { foi criado um grupo de whatsapp onde os professores tro- } \\
\text { cam ideias e informações sobre as aulas. }\end{array}$ \\
\hline $\begin{array}{l}\text { Ajuda do governo (que } \\
\text { tipo de ajuda; é recor- } \\
\text { rente ou esporádica?) }\end{array}$ & Não recebe. & $\begin{array}{l}\text { Raras vezes, conseguimos exemplares da cartilha vindos } \\
\text { da Secretaria Municipal de Direitos Humanos (SMDHC). }\end{array}$ \\
\hline $\begin{array}{l}\text { Eficiência do Projeto } \\
\text { (relevância do projeto } \\
\text { na vida dos migrantes) }\end{array}$ & $\begin{array}{l}\text { O projeto é eficiente, pois alcança o objetivo de } \\
\text { formar o aluno para uma comunicação de sobre- } \\
\text { vivência. Apesar do ensino não ser voltado para a } \\
\text { habilidade da escrita, muitos migrantes conseguem } \\
\text { trabalho, ou vão fazer outros cursos como EJA, na } \\
\text { tentativa de voltar aos estudos. Tudo é feito com } \\
\text { muita dedicação e amor, o que garante a eficiência } \\
\text { do curso. }\end{array}$ & $\begin{array}{l}\text { O projeto é eficiente, pois alcança o objetivo de ensinar o } \\
\text { aluno a se comunicar oralmente, além de conseguir reali- } \\
\text { zar as competências básicas de escrita. Na E.M.E.F Infan- } \\
\text { te Dom Henrique, os professores conseguem trabalhar o } \\
\text { ensino para o desenvolvimento da habilidade de escrita, } \\
\text { pois o curso é semestral. Logo, muitos migrantes conse- } \\
\text { guem trabalho, ou vão fazer outros cursos que os ajudem } \\
\text { a conseguir trabalhos melhores. Assim como na Missão, } \\
\text { tudo é realizado com esforço e dedicação de todos. }\end{array}$ \\
\hline
\end{tabular}

\section{Considerações finais}

Embora os novos fluxos migratórios globalizados seja uma realidade no Brasil e, mais especificamente, na cidade de São Paulo - e mesmo que o país seja signatário dos principais pactos e tratados internacionais sobre Direitos Humanos, além de possuir sua própria legislação que assegura atendimento para essa população -, a efetivação dos direitos educativos de migrantes e refugiados ainda encontra, em nosso território, diversos obstáculos.

Um deles, especificamente, está relacionado com a dificuldade de permanência no ensino escolar formal, por falta de conhecimento da língua portuguesa. Conforme citado, a dificuldade com língua dominante nas sociedades de acolhimento ganha contornos dramáticos quando ela dificulta - e até mesmo inviabiliza - não apenas o acesso aos seus direitos educativos, mas operações essenciais para essa população, tais como regularizar sua situação migratória, conseguir atendimento médico, acesso a programas assistenciais e de distribuição de renda etc.

Dessa forma, é urgente pensar em estratégias ajudem essa população a ter mais chances de permanecer na escola, acompanhar as aulas, assimilar os conteúdos propostos e participar de uma aprendizagem com relevância.

Considerando que a Pedagogia Social é a teoria que fundamenta a prática da Educação Social e que como ciência ela visa complementar a busca da educação integral - aquela que não pretende separar o "mundo da vida" do "mundo da escola" e que assume, ainda, o papel auxiliar no combate às circunstâncias que afetam negativamente os grupos sociais mais vulneráveis por meio de estratégias educativas que humanizem a pedagogia estritamente escolar e que vejam todos os espaços e relações como essencialmente pedagógicos -, investigamos neste artigo a presença (e a importância) de seus fundamentos em iniciativas do Estado e da Sociedade Civil para a oferta de cursos de Língua Portuguesa para migrantes e refugiados.

A partir da análise do conceito de Pedagogia Social, bem como da sua base freireana de sustentação aplicada à realidade da migração e do refúgio, da caracterização/ descrição do perfil dos cursos de língua Portuguesa oferecidos pela Instituição Missão Paz e do Projeto Portas Abertas, bem como do depoimento da educadora que trabalhou como voluntária também no Curso de Português para Estrangeiros da EMEF Infante Dom Henrique, chegamos às seguintes conclusões:

O ensino de língua portuguesa oferecido pela Missão Paz é marcado pela presença de muitas características e fundamentos da Pedagogia Social e suas práticas, principalmente quando se preocupa em dar aos migrantes e refugiados não apenas ferramentas decifrar o código da língua dominante, mas, também, estratégias para alcançar outros direitos essenciais, como a regularização de sua condição migratória, 
emprego digno, acesso à justiça e à saúde. As iniciativas da Instituição, em geral, atuam no sentido de desenvolver nos migrantes e refugiados habilidades e competências sociais que lhes permitam superar as condições de marginalidade, violência e discriminação que vivem em São Paulo; permitem também despertar um sentimento de participação e de protagonismo em seu processo de socialização na cidade.

Em relação ao Projeto Portas Abertas, que estabelece as diretrizes para a oferta de cursos de língua portuguesa no âmbito da Prefeitura Municipal de São Paulo, concluímos que ele está mais pautado nas práticas formais de escolarização que nas bases teóricas da Pedagogia Social. Isso porque pressupõem uma série de ações que quase sempre revelam um processo de "escolarização", e não de "educação", tais como o teste institucional de nivelamento na hora da inscrição, a obrigatoriedade de $75 \%$ de presença para a certificação e a utilização de espaço estritamente escolar para a realização das aulas. No entanto, ao apresentar um material didático que presa o ensino pelo caminho do esclarecimento dos Direitos dos Migrantes, pelo domínio e conhecimento do espaço geográfico, pelo conhecimento das características sociopolíticas do país, pela inserção digna na sociedade e no trabalho e pela troca intercultural, não podemos excluir o fato de o Projeto também possuir relevante presença dos fundamentos da Pedagogia Social em seu escopo.

No depoimento apresentado por Josefina Lopes Simões - educadora que realizou trabalho voluntário no ensino de Língua Portuguesa em diversas locais -, bem como no quadro comparativo entre o modus operandi da Missão Paz e da EMEF Infante Dom Henrique, a escola que serviu de inspiração para a criação do Projeto Portas Abertas, percebemos que ambas as ofertas cursos para o aprendizado da língua dominante possuem traços de escolarização estritamente formal e de pressupostos e fundamentos da Pedagogia Social.

O ponto forte das suas ofertas - tanto a do Estado quanto a da Sociedade Civil - é ter claro em seus objetivos a efetivação dos direitos humanos de migrantes e refugiados. As duas propostas (bem como a proposta independente EMEF Infante Dom Henrique) reconhece a importância que a educação social tem: permitir que o indivíduo participe ativamente no seu processo de socialização e cumprir um papel na consolidação do processo de libertação de grupos submetidos à marginalização, à dominação cultural e à exploração econômica - ainda que no caso do Projeto Portas Abertas isso se dê mais pela utilização do material didático.

A percepção de fundamentos da Pedagogia Social nessas duas iniciativas, porém, não nos esquiva de perceber que ainda falta o reconhecimento do profissional e do educador social, que, muitas vezes, tem seu trabalho visto como apenas voluntariado.

Por fim, concluímos que existe uma necessidade de estudar o Direito à Educação - ou os direitos educativos - dos migrantes e refugiados da perspectiva da Pedagogia Social, ou seja, para além dos estreitos limites da Educação Escolar, analisando as potencialidades que oferecem a Educação que "abrange os processos formativos que se desenvolvem na vida familiar, na convivência humana, no trabalho, nas instituições de ensino e pesquisa, nos movimentos sociais e organizações da sociedade civil e nas manifestações culturais" (LDB, 1996, art. 1).

A partir da valorização por meio de políticas públicas para a educação popular, social e comunitária - que muito equivocadamente é vista como práticas não formais, como uma educação pobre para uma população pobre -, caminharemos para a consciência de que o direito à educação não é apenas direito de ir à escola, mas o direito de aprender na escola.

\section{Referências}

ACNUR. Relatório Global Trends. 2018. Disponível em: <http://www.acnur.org/portugues/ dados-sobre-refugio/dados-sobre-refugio-no-mundo/>. Acesso em: 25 nov. 2018. 
AMADO, Roseane de Sá. O ensino de português como língua de acolhimento para refugiados. SIPLE - Sociedade Internacional de Português Língua Estrangeira, São Carlos, v. 7, 2014. Disponível em: <http://www.siple.org.br/index.php?option=com_ content\&view=article\&id=309:0-ensino-de-portugues-como-lingua-de-acolhimento-pararefugiados\&catid=70:edicao-7\&Itemid=113> Acesso em: 25 nov. 2018.

BARTLETT, Lesley; RODRIGUEZ, Diana; OLIVEIRA, Gabrielle. Migração e educação: perspectivas socioculturais. Rev. Educ. Pesqui., São Paulo, v. 41, n. especial, dez. 2015.

BRASIL. Lei Federal n. 9.474/97. Define mecanismos para a implementação do Estatuto dos Refugiados de 1951, e determina outras providências, Brasília, DF, jul. 1997. Disponível em: <http://www.planalto.gov.br/ccivil_03/leis/L9474.htm> Acesso em: 25 nov. 2018.

BRASIL. Lei Federal n. 13.445/2017. Institui a Lei de Migração, Brasília, DF, maio 2017. Disponível em: <http://www.planalto.gov.br/ccivil_03/_ato2015-2018/2017/lei/L13445.htm> Acesso em: 25 nov. 2018.

BRASIL. Lei Federal n. 9.394/1996. Estabelece as diretrizes e bases da educação nacional, Brasília, DF, dez. 1996. Disponível em: <http://www.planalto.gov.br/ccivil_03/LEIS/ L9394.htm> Acesso em: 25 nov. 2018.

CONARE. $3^{a}$ edição do relatório "Refúgio em Números", 2017. Disponível em <http:// www.acnur.org/portugues/dados-sobre-refugio/dados-sobre-refugio-no-brasil/> Acesso em: 25 nov. 2018.

HONORATO, Pricilla. A professora dos imigrantes (Docente dá aulas voluntárias de língua portuguesa para estrangeiros e refugiados em São Paulo). Todos pela Educação, São Paulo dez. 2017. Disponível em: <https://www.todospelaeducacao.org.br/conteudo/aprofessora-dos-imigrantes/> Acesso em: 25 nov. 2018.

INSTITUTO UNIBANCO. Equidade: o papel da gestão no acolhimento de alunos imigrantes. Aprendizagem em foco, São Paulo, n. 38. fev. 2018. Disponível em: <https://www. institutounibanco.org.br/aprendizagem-em-foco/38/> Acesso em: 25 nov. 2018.

IPPDH - Instituto de Políticas Públicas em Direitos Humanos del Mercosul. Migrantes regionales en la ciudad de San Pablo. Derechos Sociales y políticas públicas. São Paulo/ Buenos Aires, 2017, p. 21-22.

OIM. International Migration Flows to and From Selected Countries: The 2015 Revision. 2015. Disponível em: <http://www.un.org/en/development/desa/population/migration/data/ empirical2/docs/migflows2015documentation.pdf> Acesso em: 25 nov. 2018.

ONU. Declaração Universal dos Direitos Humanos. 1948. Disponível em: <http://www. ohchr.org/EN/UDHR/Documents/UDHR_Translations/por.pdf> Acesso em: 25 nov. 2018.

REINOLDES, Marina; MANDALÁ, Paola de Souza; AMADO, Rosane de Sá. Portas Abertas: Português para imigrantes. Prefeitura de São Paulo (SMDHC/SME): USP. 2017. Disponível em: <https://drive.google.com/file/d/1DyGcSPvSAm2YjJESP6zoUbo1T1XUTLtF/view> Acesso em: 25 nov. 2018.

SÃO PAULO. Lei Municipal n. 16.478/2017. Institui a Política Municipal para a População Imigrante, dispõe sobre seus objetivos, princípios, diretrizes e ações prioritárias, bem como sobre o Conselho Municipal de Imigrantes, São Paulo, SP, jul. 2017. Disponível em: <http://www3.prefeitura.sp.gov.br/cadlem/secretarias/negocios juridicos/cadlem/integra. asp?alt=09072016L\%20164780000 >. Acesso em: 23 nov. 2018. 
SÃO PAULO. Decreto Municipal n. 57.533/2016. Regulamenta a Lei n $^{0} 16.478$, de 8 de julho de 2016, que institui a Política Municipal para a População Imigrante. São Paulo, SP, dez.. 2016. Disponível em: <http://legislacao.prefeitura.sp.gov.br/leis/decreto-57533-de-15-dedezembro-de-2016/> Acesso em: 25 nov. 2018.

SILVA, Roberto da. Os fundamentos Freirianos da Pedagogia Social em construção no Brasil. Pedagogía Social. Revista Interuniversitaria, Sevilla, España, n. 27, jan. /jun. 2016, p. 179198.

SILVA, Sheila Agda Ribeiro da; SILVA, Roberto da; LOPES, Roseli Esquerdo. O Direito à Educação sob a Perspectiva da Pedagogia Social. 2011 (Texto elaborado em forma de relatório para a Disciplina Direito à Educação sob a Perspectiva da Pedagogia Social, ministrada pelo Prof. Dr. Roberto da Silva no $1^{\circ}$ semestre de 2011 na Faculdade de Educação da Universidade de São Paulo - FEUSP). Disponível em: <http://www.proceedings.scielo. $\mathrm{br} / \mathrm{pdf} / \mathrm{cips} / \mathrm{n} 4 \mathrm{v} 2 / 32$.pdf> Acesso em: 25 nov. 2018. 